(This an earlier version of an article that appeared in Television and New Media, vol 6, no 2, 2005, pp. 176-199).

\title{
BUFFY THE VAMPIRE SLAYER: WHAT BEING JEWISH HAS TO DO WITH IT
}

Buffy: 'We averted the apocalypse. You gotta give us points for that.' ('The Harvest')

Buffy the Vampire Slayer has become one of the great cult successes of the late 1990s and early 2000s on American television. ${ }^{1}$ The series is based on an only moderately successful film of the same name which was also written by Joss Whedon. It has become usual to argue that the relative failure of the 1992 film can be attributed to its almost reflexive, camp quality. The series, comparatively, plays the realist/Gothic disjunction relatively straight, making Buffy and her friends, nicknamed by Willow the Slayerettes, misunderstood teens. In the series the focus of the comedy has shifted from an overall campness to an ironic and referential humour embedded in the dialogue.

I will argue that, in addition to this stylistic difference between film and series there has also been a profound subtextual discursive shift. In short, where the film marks the distinction between vampires and humans, here identified with Buffy and her schoolfriends, as located in class, the division within the series utilises the tropes of race. Moving on from this argument I will discuss the Jewishness of Buffy and her off-sider, Willow, and think through the show's preoccupation with Buffy and her friends' saving the world from apocalypse. In my discussion I will focus primarily on the first two seasons.

As I have remarked, Buffy the Vampire Slayer has become a major cult hit in the USA. The first episode was broadcast on 10 March 1997. At that time Buffy was supposed to be sixteen, born in 1981. In general terms Buffy does not rank high in the Nielsen Ratings. In its first season the show consistently placed at around 100 in overall popularity. It placed approximately mid-way, six or seven out of twelve, in popularity of WB shows, the minor network which airs it. Buffy's success comes from its popularity with a particular demographic, women and men in the age-group 12-34. 
One common claim about the central character is that Buffy is a positive rolemodel for young women, a strong female with attitude who takes life's knocks and comes back with the power to confront her attackers. While there is some worth in this claim, Buffy's circumstance, especially in the series, is rather more complex. One way in which this is signalled in the demographics is that the series is watched by almost as many males in that age-group as females. In a WB press release dated 1 March 2001, Buffy gets a rating of 3.0 for all adults aged 18-34, 3.1 for all persons aged 12-34, and 3.6 for women aged 18-34, 3.9 for females aged 12-34. In addition, Virginia Rohan, a journalist with The Record Online, notes that, 'In big cities, the show's ratings are especially spectacular. In New York, during October [1997], for example, the series finished first in its time-slot among teens with a 9.3 rating and 24 share'. ${ }^{2}$ The show's survival is a consequence of its major success with this demographic, and Buffy's ability to deliver a clearly defined teen and twenties audience to advertisers.

If the show is being watched by so many younger males, what are they finding in it? Assuming that they are not watching Buffy for very different reasons to the womenvoyeurism is the everyday claim but Buffy is not Xena: Warrior Princess - then we must begin to think through what concerns the show addresses with which a generation can identify. With her usual insight and erudition Joyce Millman, in the online magazine 'salon,' argues that the component elements of Buffy are not new. She notes Buffy as 'a kickboxing TV warrior heroine in the Xena mode'. She recognises the influence of the witch sitcom tradition of shows like Bewitched, I Dream of Jeannie and Sabrina, the Teenage Witch. Had Millman's article been written the following year, she could have noted how, with another WB show, Charmed (1998), this tradition has got somewhat more serious and moved into the drama/romance genres. Millman refers to the Anne Rice element and the 'Gothic romance/star-crossed lovers theme' to be found in Buffy's involvement in the first two series with Angelus/Angel, the vampire with a soul. All up, Millman attributes the show's success to Joss Whedon's ability to 'energize his metaphors. . .with a story-telling style that is both intensely emotional and devastatingly flip'. She goes on to suggest that, 'Buffy approximates, perfectly, the mood swings of adolescence'. 3 This may be, but it does not explain why men and women in their twenties and thirties find the show so enthralling.

Such a description fits much better the Buffy character of the film. Let us then turn to the film and examine how it constructs the major protagonists. Released in 1992, 
Buffy the Vampire Slayer was written by Joss Whedon and rewritten by him along with Fran Rubel Kuzui who also directed it. Speaking about the film, Rubel Kuzui has said that, 'For me, from the very beginning, Buffy was always about 'girl power', ${ }^{4}$ This claim is important because, in the film, the narrative offers us a Buffy who moves from being a cheerleader and mindless mall-rat, such as is portrayed in the later film, Clueless (1995), to a young woman whose courage, determination and personal power enables her to take charge, killing the vampires, including their leader, the evil Lothos, and saving the other school students. In making this transition, Buffy loses her mindless friends and her vacuous boyfriend, acquiring instead a more thoughtful and helpful, if working class, boyfriend in Pike, played by Luke Perry. Certainly, we have here a narrative of girl power and yet, as I have noted, the film was not very successful, not even in the demographic among which the television show is so popular. Rubel Kuzui puts this lack of success down to a marketing problem. In her words: 'I think [the film] was never clearly marketed to one audience'. ${ }^{5}$

Centrally, the discursive system through which the difference between the humans and the vampires is expressed is that of class. Buffy and the other school students are middle-class consumers. In this consumption order, class is signified more by financial access to consumption, and what is consumed, than by the traditional Marxian productivist indicators of one's work situation. Where Buffy and the other students are all dressed in designer clothes, the vampires, with the exception of Lothos and his offsider, dress in daggy jeans, T-shirts, leather jackets and the like. Pike is, roughly speaking, the film's equivalent of Angel in the television series. Pike is not a vampire, though, however his best friend Benny becomes one and attempts to turn Pike into one also. Pike and Benny are both working class and, in the film's semiotic structure, have visually more in common with the vampires than with Buffy and the other students. In the café scene where Pike and Benny, not yet a vampire, first talk with Buffy and her friends, Pike eats loutishly and Buffy's friends make fun of the two's clothes sense and Pike's name. Pike's similarity to Angel lies in boundary transgression. Where Angel is the vampire with a soul who Buffy accepts as a lover, Pike is the working-class guy who, in becoming Buffy's boyfriend, crosses a well-patrolled class boundary—and, in the film, the boundary between vampires and humans.

Pike and Benny are car mechanics. When Buffy's friends discover that she has been associating with Pike, this is the final straw. They find the relationship 'gross', as 
one of them puts it. One way of reading the Buffy film, then, is in terms of class warfare. This is most obvious in the climactic dance scene where the dressed-up, middle-class students at the dance in the school gym are threatened by the down-market, unfashionable vampires who are excluded from the dance. In destroying the vampire threat, Buffy, with help from class-traitor Pike, not only asserts her 'girl power' but also, conservatively, makes the world-well, Los Angeles_-safe for her mall-rat ex-friends who seem to have learnt nothing from the whole episode. That is, while Buffy, as the Slayer, is transformed into a riot grrrl, the effect of her activism is to put the working-class/vampires back in their place, no longer entering the lives of young middle-class consumers but, one presumes, invisibly labouring to produce the goods for those consumers to buy as they wander the malls from which such undesirables would, most likely, be excluded.

While the vampires are working-class, their master, Lothos, is dressed as an aristocrat. This associates Lothos with the old-world vampire myth of Dracula, popularised for the twentieth century by Bram Stoker's eponymous novel, published in 1897. In the film's class narrative, Lothos' aristocracy is simply irrelevant in the New World. Where his working-class minions are reminders of an older, but still relevant, capitalist order, Lothos is simply out of place in the United States. His threat, in this reading, is fundamentally regressive, to instate a pre-capitalist, pre-democratic, political order with himself as Master.

In the film the vampires' threat to Buffy is not just that she might be killed, there is also a sexual undertone. Buffy, the blond, attractive, all-American girl played by Kristy Swanson, is also a sexualised young woman. This is immediately obvious in an early scene when, in a very short skirt, she dives across her boyfriend's male friend in the front seat of an open-top car to kiss her boyfriend. Later, in the first scene with her Watcher, Merrick, here played by Donald Sutherland, his wish to take her to the cemetery for an unexplained purpose can be read with a sexualised suggestiveness. Buffy's sexualisation intersects with what is now a common understanding of vampires, most obviously located in readings of Bram Stoker's Dracula, that vampiric blood-sucking is a sexual act. ${ }^{6}$ The 1983 film The Hunger made the relationship between vampire behaviour and sex explicit. In the film of Buffy the working-class threat is also a sexual threat. However, for Buffy, the threat is most obvious in her relationship with Lothos, the master vampire. 
Buffy's development as a Slayer seems to be intimately connected to her development as a woman. When she gets cramps that appear to be menstrual, Merrick tells her that this is a sign that a vampire is near. When she first meets Lothos, Merrick intervenes telling the vampire that she is not yet ready for him. Merrick appears to mean that Buffy is not yet a worthy opponent but the scene also has a more sexual undertone, as does the penultimate scene when Lothos comes close to biting Buffy’s neck.

I have gone into some detail about the film because we need to understand how its semantic structure differs from that of the television show, and how this relates to the unpopularity of the film and the popularity, especially among teens and twenties, of the show.

If the underlying semiotic of human/vampire relations in the Buffy film was class, in the television show it is race. The best place to start this discussion is with the humans. In Buffy vamirology, human beings have souls. Souls are what enable a human to feel emotions, and conjointly souls provide the basis for ethical behaviour. When a human becomes a vampire, is sired to use the Buffy vampirological term, (both female and male vampires can sire), a part of the change that takes place is the loss of the person's soul. In Angel's case, his soul was returned to him by the Romanies as a punishment for a murder. The return was intended to force Angel to live in the world in an agony of remorse for his

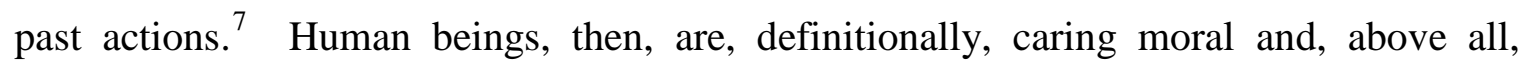
loving.

But, who are human in Buffy, the show? Less than a two hour drive on the freeway from Los Angeles, the world of Sunnydale is implacably white, and not only white but Anglo-white. By this I mean that, if we look at the names of the major human characters, none have even central or eastern European-suggestive names, or southern European names. A quick role-call of the major characters will easily demonstrate this point. We have Buffy Summers, Xander (short for Alexander) Harris, Cordelia Chase, and later $\mathrm{Oz}$ (Daniel Osbourne). Rupert Giles is white and English. Finally, there is Willow Rosenberg who is Jewish. I will have more to say about her whiteness presently. Now, if the main characters are Anglo-white, then a quick perusal of the rest of the students at Sunnydale High suggests that they are all white as well.

This phenomenon of whiteness is not confined to Buffy, we should note. Pete Schulberg in an online think-piece for The Origonian, from July 1999, writes that: 'If 
you're not white, young and attractive, you might as well kiss your network series career goodbye'. ${ }^{8}$ More specifically, Schulberg notes that: 'None of the 33 network series set to debut this fall [1999] on ABC, CBS, NBC, Fox Broadcasting and WB include a major character who is African-American'. Finishing his article by commenting on what were then two forthcoming shows, Schulberg writes:

'Having seen tapes for Roswell and Popular, I see that the two high schools where the action takes place are glaringly devoid of minorities. It's hard to spot anyone of color, even among the extras'.

Buffy, then, is part of a general pattern. We can add that, in the transition from film to television, and from Los Angeles to Sunnydale, Buffy loses her one African-American friend.

The human world of Buffy, the television show, is remarkably homogeneous, full, as I have said, of Anglo-Americans. These humans/Anglo-Americans all have, of course, souls. In the Introduction to the cast descriptions in Buffy the Vampire Slayer: The Watcher's Guide, vol 1, we are told:

'Joss Whedon [the creator and chief writer] says of the world of Buffy the Vampire Slayer: “At the core, it's an emotionally safe place to be”. The main characters care deeply about one another (yes, even Cordelia), and when the chips are down, they can count on one another. They share a common vision, and they serve a common purpose. They are loyal and true, and yes, they would die for one another.

What all that is, is love'. ${ }^{9}$

Humans/Anglo-Americans love each other. Non-humans, vampires and demons, do not. Non-humans in this Buffy universe are non-Anglo-Americans. To make the point clearer we can broaden this high level of homogenization and say non-whites, members of other races, do not have souls - that is to say, consciences, ethics and, of course, the ability to love.

Before we move on, there is one more point to make here about the quotation above. It amplifies the relationship between Buffy and her friends noting that they 'share a common vision' and 'serve a common purpose'. To me, this sounds very much like the nineteenth century ideal of the nation which we can define in shorthand as a racially homogeneous group of people bound together with a shared culture and a shared sense of 
their own future. ${ }^{10}$ In the United States the latter idea evolved into the notion of a Manifest Destiny, a term coined by the journalist, John L O’Sullivan in the early 1840s to justify American expansionism. In this imagining, race was naturalised as an essential quality. One of the things that is comforting for an Anglo-American viewer is that they see an image of a United States - after all, all the main human characters except for Giles have American accents-that is Anglo-American and unified in purpose. There are no 'minorities' here, no need for debates over affirmative action, no racially-based demands for multicultural acknowledgement.

Before elaborating on this point I want to discuss further the question of accents. Within this all-white world, accents become very important as markers of difference. Thus, Rupert Giles' Englishness is signalled to some extent by his clothes and, to at least the same extent, by his accent. Now, Giles is Buffy's Watcher-her second in actual fact-and his Englishness suggests a connection with the Old World, the European world from whence the threatening vampires came but also the safe, white, English world which established the colony that became the United States and now lends its knowledge to help the US, in the person of Buffy, and her friends, defend itself against vampire depredations.

However the use of Englishness is rather more complex than this for two of the most regular vampires are also 'English' in accent, though played by American actors, Drusilla and Spike. Here, we have the remnants of the class warfare discourse that is so prominent in the film. Drusilla's accent places her as cockney, or at least, London East End, while Spike's suggests an upwardly mobile working-class lad. Indeed, to me, with his bleached blond hair and clipped manner Spike stands in a line of images that tracks back to the late 1970s and early 1980s singer, Billy Idol, originally in the English punk band Generation X, and also to the characters in The Who's remake of mod life in the mid-1960s, Quadraphenia (1979) in which Sting plays Ace the blond-haired mod style leader. $^{11}$ Drusilla and Spike's working-class English accents do a double duty. They mark the ancientness of vampires from an American point of view and signal Drusilla and Spike's difference from the middle-class world of Giles, and of Buffy and the rest of Sunnydale High. At the same time, Drusilla and Spike's whiteness does not disturb, or make overt, the racially-based human/vampire coding of the show.

Angel speaks English with an accent that was originally partly Irish, his origin, and partly American. As the show proceeds it gets more American. Angel was sired as a 
vampire by Darla in the Irish city of Galway in 1753. The Irish are, if you like, the distaff aspect of Anglo-American whiteness. Through the eighteenth and nineteenth century, when Ireland was colonised by the English, the Irish were represented as racially different, as associated with Negroid blackness. ${ }^{12}$ In the nineteenth century in the United States, the Irish tended to be grouped with African-Americans. As Noel Ignatiev describes, the whitening and assimilation of the Irish into Anglo-American society took place through the nineteenth century. ${ }^{13}$ He writes that: 'The outcome was not a foregone conclusion ... while the white skin made the Irish eligible for membership in the white race, it did not guarantee them admission; they had to earn it'. ${ }^{14}$ They earned entry into American whiteness by identifying with the causes of white Americans including supporting slavery, and distinguishing themselves from African-Americans. Thus, in the terms of the Buffy show's very limiting and selective account of who is really an AngloAmerican/American, Angel's status as a vampire with a soul expresses his ambiguous position as an Irishman in the USA, both white and not-completely-white.

It is also important to mention Janna/Jenny Calender here, though I will have more to say about her later in the context of how the show activates similarities and differences between Romanies and Jews. Jenny marks the limits of Buffy whiteness. Her American English is perfect yet her background as a Gypsy from Romania suggests her eastern European exoticness. Jenny's real name is Janna, she has taken the very Anglo name 'Jenny Calender' to pass at Sunnydale High where she gets a position as a computer-science teacher. Jenny is played by the Italian-American actor Robia La Morte whose dark looks contrast with the rest of the main characters. Jenny marks the limit of Buffy whiteness, of safe Anglo-Americanness. It is her accent which, in the end, makes her safe, and it is not surprising that, as an adult, she is described in her biography in The Watcher's Guide as: 'A very modern woman, Jenny dressed in similar fashions to her students, spoke in slang, and had an excellent rapport with her students' ${ }^{15}$ Her extreme assimilation into student life at Sunnydale High counterbalances her marginal whiteness. However, neither this nor her romantic involvement with Rupert Giles is enough to save her. In 'Passion' she was murdered by Angel after he had again lost his soul.

Finally, we come to the one fully non-white character to be included, albeit briefly, in Buffy's group. Kendra is a Slayer. Although only one Slayer is supposed to be active at a time, Kendra was activated when Buffy briefly died at the hands of the Master in 'Prophecy Girl'. Kendra was played by the African-American actor Bianca Lawson. 
However, fitting in with the show's semiotic project of excluding American racial minorities, Lawson does not play Kendra as an African-American. Rather, as The Watcher's Guide puts it: 'Her accent suggests a background on a British, or formerly British, Caribbean island, but her homeland is never identified by name'. ${ }^{16}$ Lawson herself describes the accent as Jamaican and adds that, “ "it was like the lower class, with a heavier patois", ${ }^{17}$ Nevertheless it was not a broad Jamaican accent and still suggested to those familiar with the accent a more middle-class background. With Kendra we can appreciate how important accents are in this white world. Kendra's accent makes her relatively safe, as did Jenny Calender's, marking her as non-American and also as Jamaican with its connotations of being an ex-British colony. Again, though, all this was not enough to save Kendra and allow her to take a place in the Anglo-American Buffy community. Kendra appeared in three episodes only, being killed by Drusilla in 'Becoming, Part 1'.

What, then, in this reading, is the apocalypse from which Buffy, and her friends, save the world? If vampires and demons are soulless, racial Others threatening Buffy's loving, Anglo-American, white world, then what we have is some sort of race warfare fear, fear that the racial Others are trying to take over, and destroy, the Anglo-American world. Let us position this anxiety more specifically. Buffy first went to air in 1997. It is set in a peaceful all-Anglo-American, white town, Sunnydale, outside of Los Angeles. Yet, the 1990s in the United States, and especially in California, were anything but peaceful. Dale Maharidge begins his Foreword to the 1999 edition of his 1996 book, The Coming White Minority: California, Multiculturalism, and America’s Future, by writing:

'Whites are now a minority in California.

The crossing of this threshold went unheralded when it occurred sometime in $1998{ }^{\prime}{ }^{18}$

Maharidge goes on to write-making a slippage between white Americans and Americans that would do justice to Buffy: 'Americans elsewhere have grown to realize in the past few years that what is happening in California is their future as well' ${ }^{19}$ Maharidge writes that, 'By 2050 the nation will be almost half non-white' ${ }^{20}$ At this time the forecasts suggest that 'Hispanics will make up 21 percent of the American population, blacks 15 percent, and Asians and Pacific Islanders 10 percent. $^{21}$ Already whites have become a minority in many major cities: 
'The 1990 Census found that 51 out of 200 cities with populations over 100,000 were minority-majority communities. New York city is, of course, the prime example'. ${ }^{22}$

We should recall here Rohan's comment that the viewing figures for Buffy are 'especially spectacular' in the big cities, and that she singled out New York in particular.

Sunnydale, we know, is over a Hellmouth, a site of mystical convergence. Acknowledging the previous Spanish/Mexican colonisation of California, we know from 'Welcome to the Hellmouth' that the Spanish name of the town has been Boca del Infierno. Alta California, along with what is now Utah and Nevada, and parts of Arizona, Colorado, New Mexico and Wyoming, formed the area of Mexico ceded to the United States at the Treaty of Guadalupe which ended the American expansionist MexicanAmerican War in 1848. In the naming imagry where Sunnydale replaces Boca del Infierno, we have a white Anglo-American civilisation supplanting a Spanish-originated 'hell'. We can note by the by, that there is no recognition here of a pre-colonial world other than the vague idea that this Hellmouth has 'always' existed.

Even though sunny, white civilisation has come to Sunnydale, the vampires still come through the Hellmouth and civilisation is threatened. Maharidge tells us that: 'According to a 1995 US census report, 25 percent, or 7.7 million, of the state's [California's] residents were born outside the United States, most in non-white nations' ${ }^{23}$ In the American racial system Hispanics are non-white so this figure includes Mexicans coming into California. The Hellmouth, then, can be read as a metaphor for the site of non-white migration, both legal and illegal, into California and the United States more generally. $^{24}$

Maharidge sums up white anxiety at the end of the century, especially after the Los Angeles riots of 1992 like this:

'whites are scared. The depths of white fear is under-estimated and misunderstood by progressive thinkers and the media. Whites dread the unknown and not-so-distant tomorrow when a statistical turning point will be reached that could have very bad consequences for them. They fear the change that seems to be transforming their state into something different from the rest of the United States'. ${ }^{25}$ 
And middle-class whites are fighting back, especially at the ballot box. There was, for example, Proposition 187 which was passed in 1994 denying illegal immigrants access to public services. In 1996 the anti-affirmative action Proposition 209 was passed and, in 1998, the passing of Proposition 227 ended bilingual education in California. Earlier, in 1986, there had been a ballot to declare English the official language of California. In this context, Buffy, the apparently all-American, Anglo-American middle-class girl, blond though not blue-eyed, ex-cheerleader, can be read as the saviour of white society, slaying the vampires and demons who wish to take over the world, the United States, in a racial apocalypse. ${ }^{26}$

Now we have a way of understanding the show's appeal to the 18-34 demographic. Of course, we do not have any race-based viewing figures but, given the racial composition of the characters, it is highly likely that the majority of viewers are 'white'. What the show presents is a reassuringly white world in which whites fight back against the apocalyptic threat of being overwhelmed by other races.

II

At the end of the previous section I described Buffy as only apparently the allAmerican girl. I now want to rework the race-based reading of the show that I have developed, inflecting it with a Jewish reading. Unlike Kristy Swanson's Buffy in the film, there is something just a little not-quite-right about Sarah Michelle Gellar's Buffy. She seems to be the all-American, blond teenager, and yet there is something in the way she looks that suggests all is not quite as it seems. Marcia Shulman, the casting director for Buffy, hints that this is exactly why Gellar was chosen for the part when she 'reveals that the producers had a very good idea of what they wanted in the actress who would play the title role-until Sarah came along'. ${ }^{27}$ Gellar's just-so-slightly disconcerting difference may well be there to signal her slayer status; she is, after all, not quite like other mortals, being stronger and having faster reflexes. Gellar's skin is just a little too olive for your run-of-the-mill natural blond. Her full face and high cheek-bones are also not quite normative for an Anglo-American woman. As it happens the blond hair is not genuine. Gellar's natural colour is brunette.

Gellar's father, it turns out, is Jewish. While her mother is not, the genetic descent is there, and, though according to halakhic (traditional Jewish) law, Gellar would not be Jewish, in 1983 the Central Conference of American Rabbis decided that a child 
born to either a Jewish mother or father should be regarded as Jewish. In the show Gellar passes for Anglo-American Buffy Summers, daughter of Joyce Summers played by Kristine Sutherland who is an Anglo-American. Sutherland's hair happens to be its natural colour when she plays Joyce Summers, a blond-brunette mix. Thus, Buffy's slayer difference turns out to be the effect of Gellar's Jewish difference. Interestingly, Kendra's slayer difference is marked by her racial difference as signified by her black skin.

However, we should not get too essentialist here, especially as Buffy’s best friend and off-sider, the Jewish Willow Rosenberg, is played by Alyson Hannigan who is not Jewish. One effect of this is visually to reinforce Willow's assimilation. Although coming from what is implied to be an observant Jewish home, Willow evidences no obvious sign of her Jewishness in her public, day-to-day, life. Willow, indeed, acts out the cultural pluralist ideology of keeping her Jewish difference for her private, home life

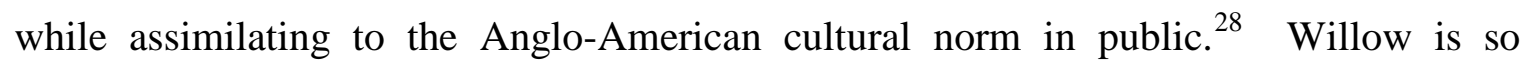
assimilated that it is not until episode 12 of the Second Season, 'Bad Eggs', that we get any sign of her Jewishness other than her family name. With the Anglo-American assimilationist ethos of the show in mind, it also seems to be the case that Willow is the only Jew at Sunnydale High. Willow is lucky in that she is not subject to any antiSemitism, but this may be because she is so assimilated that many students are most likely not aware of her Jewishness and, also, she does not 'look Jewish'-which is not surprising given the actor who plays her! A generation earlier, Stephen Spielberg has recounted the constant anti-Semitic harassment to which he was subjected at Los Gatos High School in Northern California. ${ }^{29}$ One way of reading the lack of anti-Semitism against Willow is the historical 'whitening' of American Jews that I shall discuss shortly, however, a more likely reading, more in tune with the show's racial fantasy, is that the lack of anti-Semitism offers American Jews a fantasy image of their acceptance into Anglo-American society.

Not surprisingly, then, Gail Berman, executive producer and the woman instrumental in getting Buffy to air as a television show, has this to say about Willow:

'I love Willow's character, I love what's going on with her and Xander, and $\mathrm{Oz}$ - it feels real to me. I love the fact that she is Jewish-I can't recall ever having a Jewish character on television that isn't portrayed in 
some stereotypical way. For me that is very helpful to say to my daughter:

Willow's Jewish'. ${ }^{30}$

What Berman seems to mean here is that Willow has not been given any obvious Yiddish identifying markers such as her physical appearance, her accent, her lack of Yiddish grammatical constructions in her speech, lack of Yiddish words and phrases, lack of 'uncivilised' excitability and so on. From the point of view of her presentation of self, Willow could be Anglo-American.

Yet, in other ways, Willow falls precisely into the Jewish stereotype. Willow's difference comes out in her awkwardness relating to people. This is identified as her being, 'A fairly reserved and shy person'. ${ }^{31}$ Willow is a nerd, a computer freak. She also loves reading and is the only one of the friends who has used the school library. She is on her way to being an intellectual. After Jenny Calender's murder, Willow is asked to take her computer-science class until the new teacher arrives. Willow discovers her vocation, she loves teaching. Here, we have the stereotypical cultural construction of the assimilated Jew, awkwardness - the stereotype has the Jew with a rather weedy body, while this does not apply to Willow she is certainly not strong and not good in fightsnerdiness, the intellectual bent leading logically to teaching. Willow's loveable weakness is exemplified in her response to Buffy's remark in 'Becoming, Part 1' that if she fights Angel and loses 'Willow might be our only hope', to which Willow replies: 'I don't want to be our only hope, I crumble under pressure. Let's have another hope'. Interestingly the qualities I have identified are most usually associated with Jewish men. Woody Allen comes to mind as an example. The equivalent images for Jewish women are the Jewish American Princess and the neurotic mother. It is the transposition that makes the stereotype harder to recognise. It is also the case that, compared to the negative stereotypes of Jewish women, the male stereotype of the Jewish nerd is much more positive.

Willow's cultural pluralist assimilation into white Anglo-American society can take place because her Jewishness is not identified racially. Rather, it is religious and cultural. Willow's biography in The Watcher's Guide, vol 1, describes her as coming from 'a very Jewish household'. ${ }^{2}$ This seems to be an extrapolation from Willow's remark that, as a kid, she used to have to go round to Xander's house to watch Charlie Brown's Christmas, and her mentioning to Buffy that her father would be horrified that she was putting up crucifixes in her room, this is to keep Angel out. However, Willow is 
clearly nowhere near as observant as her parents. For example, neither her boyfriends nor girlfriend — when she comes out as a lesbian-are Jewish. In a United States where interracial relationships are still an oddity, Willow's unrequited love for Xander, and subsequent relationships with $\mathrm{Oz}$ (Daniel Osbourne) and later Tara, emphasise not only her assimilation and loss of Jewish values but also her whiteness, her acceptability in, as a part of, Anglo-American society.

In this regard we can usefully compare Willow, the Jew, with Jenny, the Romany. Both Jews and Gypsies have been regarded as outcasts from modern society, as diasporic wanderers owing no deep allegiance to the nation-states in which they found themselves. However, as Karen Brodkin has argued, in post-World War II United States, Jews were reconstituted as white and incorporated into Anglo-American society. ${ }^{33}$ Thus, while Willow, with her non-Jewish New Age name, is Jewish through religion and culture-in 'Bad Eggs', when the students are given eggs to look after she asserts that hers is Jewish and that she will teach it Jewish values-Jenny is so marginally white that, as I have discussed earlier, she even has to change her name. Where Willow, and Jews generally, are, in fantasy and to some extent in reality, accepted into American society as 'white', and American, Janna/Jenny is constructed as Old World, as eastern European. Janna/Jenny was given the background that many Jews in the US have with the effect that Willow is whitened even more through the contrast.

One way of thinking about Willow and Buffy is that they are a Jewish fantasy couplet along the lines of Clark Kent and Superman. The idea of Superman with his mild-mannered alter-ego, Clark Kent, was developed by two Jews, Jerome Siegel and Joseph Schuster in the early 1930s. In the Willow/Buffy couplet, Willow is the physically weak, intellectual Jew while Buffy is the passing 'tough Jew', to use Paul Brienes' term. ${ }^{34}$ Brienes argues that, in the latter part of the 1960s, especially after the Six Day War of 1967, there evolved in the United States a new image of the tough Jew who was prepared to stand up and fight to defend his (six) people. Such an image has been integral to the construction of the native-born Israeli Jew, the sabra, since the inception of the Israeli state. Thus, in Willow and Buffy we have not so much the 1930s Jewish-American assimilationist fantasy of becoming the superhuman goy but more a complex complementarity of images. In Willow we have the older, diasporic, eastern European-originated image of the ineffectual, bookish, but morally worthy Jew. These European Jews are also the ones that Israeli, and also Jewish-American, mythology have 
as walking unresistingly into the Nazi gas chambers. In Buffy we have the tough Jew, physically strong though not very intellectual, ready to defend her people even at the cost of her own life.

What I am beginning to suggest here is that there can be read into Buffy, both the film and the television show, a Jewish subtext that is much more pervasive than the presence of a single Jewish character. In the film of Buffy, in which, as I have already argued, the structuring discourse is class, there is no Jewish character, no Willow-the film is set in Los Angeles, in narrative terms before Buffy and her mother go to Sunnydale-and there are no Jewish undertones to Buffy and her friends. Rather, Jewishness is played out in a vampiric echo of the Holocaust in the characters of Buffy's Watcher, Merrick, and Lothos, the master of the vampires. Now, while Donald Sutherland is not Jewish, he plays Merrick wearing a felt trilby hat and clothes reminiscent of a pre-World War II eastern European migrant, including an accent which, while not clearly Yiddish, is not quite fully American. It is, therefore, not surprising that, when Buffy asks him what sort of a job he would have liked had he not been a Watcher, Merrick replies, 'a job-I would have made a wonderful bootmaker'. Shoemaking, along with the clothes trade, was one of those occupations stereotypically associated with eastern European Jews. For comparison, the flashback scene in 'Becoming, Part 1', which shows Buffy meeting Merrick for the first time, is quite different from the original scene in the film. Aside from being in a different location, outside the school rather than in the gym, Buffy is now played by Sarah Michelle Gellar and Merrick by Richard Riehle who portrays the part of the Watcher very differently from Donald Sutherland. This Merrick looks like a rather faded American gentleman, overweight with a large moustache, rumpled white shirt and tie, and a blazer. I have already discussed Lothos in class terms as having the image of an aristocrat, now I can add that he is played by the most Aryan-looking actor in Hollywood, Rutger Hauer, and that his cravat is held in place with what looks to be an iron cross. Lothos is reminiscent of a combination of the decadent aristocrat and a Nazi SS officer from Luchino Visconti's film The Damned (1969).

In other words, while class is the dominant discourse in the film, the vampiric threat is also, to some extent, figured in terms of the Nazi genocide of European Jewry, the Holocaust. This reference becomes much stronger in the show, as I will explain. In the film the only other Jewish reference, in addition to Merrick's Jewish connotation, is 
the name on the gravestone of the youth who, having been killed three days earlier, rises from the dead while Merrick and Buffy are in the cemetery. It is Robert Berman.

Where the Jew/Nazi Holocaust undertones are muted and limited in the film, in the show, where the discourse of race is the main structuring force, the references are much more important. I have already discussed Willow and Buffy as Jewish types. It is now necessary to say something about the Nazi qualifications of The Master as he appears in the television show. The Master dominates the vampiric evil of the show's first season. It transpires, though never revealed on television, that his name is Heinrich Joseph Nest. ${ }^{35}$ Neither Heinrich nor Joseph are common names in post-World War II Germany because Himmler's forename was Heinrich and Goebbels was Joseph. Heinrich Himmler was Reichsführer of the SS and responsible for the implementation of the Final Solution, the genocide of the Jews. Joseph Goebbels was Hitler's Minister for Propaganda who had a particular hatred of Jews. Thus, the Master's name carries the connotations of two of Hitler's most powerful associates. Joseph was also Stalin's forename. For those who know their Nazi history, Nest connotes Eagle's Nest. This colloquial term is usually thought to refer to Hitler's residence in the Bavarian village of Obersalsberg where there was also the southern centre for military operations. However the term more properly applies to Hitler's Teehaus which was perched on the very top of the mountain. In 'The Harvest' we are told that the Master arrived in Sunnydale from overseas sixty years earlier from 1997 when the show went to air, and that he came 'not just to feed'. It seems that the Master knew that Sunnydale was built over the Hellmouth and that he wanted to open it to allow the demons out to walk the earth once more. ${ }^{36}$ Now, sixty years before 1997 places the Master's arrival in 1937, when the Nazis were consolidating their power in Germany and beginning their persecution of the Jews. At the same time the American Nazi Party was at its most powerful.

How, then, to think of this vampiric threat that the Master brought to Sunnydale, and the greater threat that he attempted to unleash, thwarted only by a chance earthquake that trapped him in the Hellmouth? Even after the Master's death this greater threat of a vampiric or demonic apocalypse remains. ${ }^{37}$ We can now rework the idea of a racial apocalypse, rereading it as a fear marked and connoted in the show by reference to the Jewish Holocaust which was, of course, founded on the Nazi racialisation of the Jews. In this reading the Nazis are soulless, threatening vampires determined to destroy American society figured not just as middle-class Anglo-American but, ultimately, as Jewish. 
The figuring of the Nazis as vampires inverts a long-standing anti-semitic usage of vampires as a way of describing Jews. For example, in the United States, Benjamin Franklin used the metaphor in the course of an anti-Semitic diatribe during a break in the Philadelphia Constitutional Convention of 1782. He said:

'For 1,700 years, the Jews have been bewailing their sad fate in that they have been exiled from their homeland, as they call Palestine. But, gentlemen, did the world give it to them in fee simple, they would at once find some reason for not returning. Why? Because they are vampires, and vampires do not live on vampires. They cannot live only among themselves. They must subsist on Christians and other people not of their race'. 38

In the 1860s, Wolfgang Menzel, a German literary critic, 'described how the Jewish literati robbed the German people of its national vigour: "The Jewish demon fanned it [the people] with its vampire wings, while it gently sucked away its blood.", 39

Hitler, himself, used the image in Mein Kampt when describing his claim that the Jewish Bolshevik take-over of Russia had resulted in the deaths of thirty-nine million people:

'The result is not only the end of freedom for the people oppressed by the Jews, but rather also the end of these parasites of the peoples themselves.

After the death of the victim, the vampire dies sooner or later'. ${ }^{40}$

The metaphor continues to have currency in anti-semitic circles. In 1996, the Milli Gazette, the organ in Europe of the Turkish ultra-nationalist organisation Milli Gorus (National Vision), describes Jews as 'blood-sucking vampires' and Western countries as 'instruments of the secret Jewish worldwide conspiracy'. ${ }^{41}$

The reversal of use is founded on a moral reversal. Anti-Semites think of Jews as an evil force, an evil race, parasitic on a fundamentally moral world and conspiring to destroy it. In Buffy, the vampiric racial Others are evil, trying to destroy Anglo-American civilisation and all it stands for. While what conjoins the present-day racial apocalypse reading with the Holocaust reading is that both are premised on the show's distinction between humans and vampires as operating in the discourse of race, the Nazi genocide of 
the Jews is being invoked as a way of justifying white, Anglo-American fear and legitimating white aggression.

This said, we need to understand how Buffy, both film and television show, is historically located in relation to the Holocaust. The term 'Holocaust' for the genocide of the Jews has an obscure pre-history during World War II, however through the 1950s the most common description was by way of a reference to concentration camps. ${ }^{42}$ It seems that the Israeli memorial to the Jewish dead, Yad Vashem, began using the term in the late 1950s and, according to Paul Brienes in Tough Jews, it gradually entered American usage during the 1960s. ${ }^{43}$ The term seems to have become capitalised, marking the increasing use of the event it describes as a moral touchstone, in the late 1960s and early 1970s. The breakthrough to its general acceptance in popular Western culture as the way to describe the Nazi genocide of the Jews was in some part a consequence of the broadcasting in 1979, in the United States in the first instance, of Holocaust, a mini-series about the genocide.

Jeffrey Shandler writes: 'At the same time that Holocaust prompted millions to discuss the Nazi persecution of European Jewry, it also engendered an extended public exchange on the representation of the Holocaust on television' ${ }^{44}$ Elie Weisel, survivor and one of the loudest objectors to attempts to represent the Holocaust, published an article in the New York Times entitled, 'Trivializing the Holocaust' in which, 'he denounced Holocaust as transforming “an ontological event into soap-opera”, 45 Thus, the mini-series both popularised the genocide of the Jews in the discursive form of the Holocaust and set the parameters for an ongoing debate over the possibility of its representation. The locus classicus of this debate is Saul Friedlander's edited collection entitled Probing the Limited of Representation: Nazism and the "Final Solution", published in 1992. ${ }^{46}$ The next year Steven Spielberg released the first feature film to attempt directly to portray the events of the Holocaust.

Yosefa Loshitzky argues that, 'Schindler's List (along with the Holocaust Museum in Washington) can be viewed as part of a symbolic rite of passage introducing the Holocaust into mainstream American culture' ${ }^{47}$ Holocaust was marketed as a one-off special event, in an important sense Schindler's List normalized the Holocaust, acknowledged its availability for narratival realism. At its most basic this has to do with a generational shift that was taking place. Loshitzky puts it this way: 
'Today, the desire to represent (as well as to "consume”) the Holocaust is motivated by a deep anxiety nurtured by the gradual disappearance of Holocaust survivors - the last eyewitnesses to a catastrophe-from the land of the living. Steven Spielberg's Schindler's List may be seen as the great locus of this angst. . . . the film reifies the fragile moment of transition in historical consciousness from lived, personal memories to collective, manufactured memory'. ${ }^{48}$

Here, Loshitzky is making explicit the important connection between a generational shift from survivors who lived through the events of the Holocaust, many of whom like Weisel feel that it cannot be fictionally depicted without some crucial loss, who are now dying and th4e second and third generations since the Holocaust, and the movement towards functionalised representations as a way of preserving memory.

Now, the television show of Buffy first went to air four years after the watershed of Schindler's List. Of course, Buffy does not offer us a representation of the Holocaust. Rather, it can be read as refiguring the Holocaust in the Gothic terms of vampire and demon threat. More significantly the show draws on the affect associated with second and third generation Holocaust survivors as a way of comprehending the racial apocalypse implicated through the show's utilisation of the discourse of race. In order to understand this generational, and indeed communal, transference of the affect of trauma we can refer to Marianne Hirsch's theorisation of what she calls post memory:

'Postmemory is a powerful and very particular form of memory precisely because its connection to its object or source is mediated not through recollection but through an imaginative investment and creation. This is not to say that memory itself is unmediated, but that it is more directly connected to the past. Postmemory characterises the experience of those who grow up dominated by narratives that preceded their birth, whose own belated stories are evacuated by the stories of the previous generation shaped by traumatic events that can be neither understood nor recreated. ${ }^{49}$

Hirsch is writing about the handing on of traumatic affect within families, from parent(s) to children. I would like to generalise this idea to the Jewish community but also, in the context of Buffy, to the white, Anglo-American community in its 'Jewished' reformulation. 
What I am arguing here is that, as American society has taken up the Holocaust as the site of a moral absolute, so the traumatic affect of the Holocaust gets expressed in ways that break the bounds of narrative realism. From this point of view Buffy, the nonJewish-but-Jewish character, evinces many of the characteristics of second, and indeed more properly third, generation trauma and, more generally, the show acts this out. ${ }^{50}$ We might start quite banally by thinking about the dreams of past slayers and their destruction at the hands of vampires that Buffy has before she is told that she is a Slayer. These are more obvious in the film than the television show which begins after the introductory events of the film. Dreams, as Freud realised, are an important site of the return of the repressed. Ruth Leys writes that, 'the general problem of repetition, especially the tendency of traumatized people to repeat painful experiences in their dreams ... compelled Freud in Beyond the Pleasure Principle (1920) to acknowledge the existence of a "beyond" of pleasure, or death drive, acting independently of and often in opposition to the pleasure principle. ${ }^{51}$ The repressed that is handed down from one generation to the next in the form of postmemory can, likewise, be expressed in dreams. In the show Buffy also has prescient dreams about the future. Just as the show displaces the repressed Holocaust onto the fear of a future racial apocalypse, so Buffy's dreams work to displace the return of past trauma with an imagining of future trauma.

In an important paper given at the Twenty-ninth Annual Conference of the Association for Jewish Studies in 1997, Lucia Ruedenberg-Wright, talking about second and third generation survivors noted that:

'Many second generation come from families where the underlying dynamics are shrouded in a "conspiracy of silence". The impact of a "return of the repressed" within these families depends on the severity of the parents' conflicts and the susceptibility of each child'. ${ }^{52}$

While Buffy herself appears to suffer from the return of others' repressions, the show acts out the return of a repressed experienced as either too awful to depict realistically or that has too much affect for a realistic portrayal to do it justice.

Ruedenberg-Wright explains that: 'Many clinicians note that an important characteristic of the second generation is that they have fantasies about their parents' past'. ${ }^{3}$ As a show, Buffy produces the affect of the postmemory of the Holocaust in fantasies played out in the present. In one of the as yet very few sites on the Web 
dedicated to third generation survivors, Gilad Evrony tells his story. At one point he writes:

'Of all the emotions conjured up by my Grandfather's story, one stands out the most. Here I am sitting in a beautiful house, free from oppression, free from hunger, free from anything that could restrict my freedom, yet only fifty years ago, six million Jews experienced exactly the opposite. They went through a hell which I can hardly even fathom. I was filled with feelings of guilt, horror, and sadness. . .54

Evrony describes the Holocaust as a hell he can hardly even fathom. He emphasises the contrast with his life today. Buffy can be read as enacting the affect of Evrony's characteristic feelings of guilt, horror and sadness in a Gothic structure where the Nazi past has returned to haunt the safe, suburban present. In this world, in every episode, Buffy the tough Jew, rallies her forces including the 'weak' diasporic Jew, and goes out to patrol, restaging the Holocaust only this time, every show, rather than the Nazi vampires and demons winning and sending the Jews to the concentration camps, Buffy rewrites the past saving grandparents and parents with the Jews winning and the Nazi vampires destroyed. ${ }^{55}$

To recapitulate: what I am arguing is that the television show of Buffy works through the discourse of race, and of racial apocalypse. However, it draws its affect from the Jewish experience of the Holocaust. The show can be read as a second and third generation postmemory revisiting of the Holocaust where this time the tough Jews of the United States fight off and destroy the Nazi threat figured in the show's vampires and demons. While the show offers itself to be read as an expression of white AngloAmerican anxiety at the changing racial composition of California and the United States more generally, the affect it brings to this expression is that of second and third generation Holocaust survivors. This is one example of the way that the Holocaust affect has been generalised or, at least, transferred to another context, as the Holocaust itself has become generalised in the 'West', and particularly the United States, as a moral reference point for all Anglo-Americans, all Americans and, in Buffy's terms, all humans. 
Buffy the Vampire Slayer has already spawned two academic edited collections: Rhonda V Wilcox and David Lavery eds Fighting the Forces: What's at Stake in Buffy the Vampire Slayer Rowman \& Littlefield, 2001, and Lisa Parkes and Elana Levine eds Red Noise: Buffy the Vampire Slayer and Critical Television Studies Duke University Press 2002. There is also an online academic journal devoted to Buffy the Vampire Slayer called Slayage.

Virginia Rohan 'Nielsen rank doesn't tell the whole story' The Record Online, 16/11/97 at http://www.bergenrecord.com/yourtime/hiddenhit1997.11162.htm

These quotations come from Joyce Millman 'Why Must I Be a Teenage Vampire in Love?' Salon at http://www.salon.com/ent/tiv/mill/1998/06/08mill.html

Fran Rubel Kuzui interview in Christopher Golden and Nancy Holder Buffy the Vampire Slayer: The Watcher's Guide, vol 1, Pocket Books 1998, p. 248.

Fran Rubel Kuzui interview in Buffy the Vampire Slayer: The Watcher's Guide, vol 1, p. 248.

Traditionally, a vampire is created by a human having their blood sucked by a vampire. In the Buffy television show's vampire lore a vampire can only be created if the human and the vampire suck each other's blood. In a sexual reading perhaps this can be read as equality in sexual practices.

For further details on Angelus/Angel see Buffy the Vampire Slayer: The Watcher's Guide, vol 1, ‘Angelus’ pp. 127-129.

Pete Schulberg 'Lack of African American roles dominates press tour'. The $\begin{array}{llll}\text { Oregonian } 21 & \text { July } & 1999 . & \text { http://olive- }\end{array}$ live.webnet.advance.net/ent/tv/99/07tv990722_schulberg.html

Buffy the Vampire Slayer: The Watcher's Guide, vol 1, p. 196.

The historical understanding of the nation is very complex, see, for example, Ernest Gellner Nations and Nationalism Blackwell 1983; E J Hobsbawm Nations and Nationalism Since 1780: Programme, Myth Reality Cambridge University Press, $2^{\text {nd }}$ ed 1992. I make the argument about race, nation and homogeneity in chapter 1 of Jon Stratton Coming Out Jewish: Constructing Ambivalent Identities Routledge 2000.

Mods were an English working-class youth culture of the mid-1960s. They were upwardly mobile. On mods see Dick Hebdige Subculture: The Meaning of Style Methuen 1979, also Stanley Cohen Folk Devils and Moral Panics: The Creation of Mods and Rockers MacGibbon and Kee 1972.

On this see Anne McClintock Imperial Leather: Race, Gender and Sexuality in the Colonial Conquest Routledge 1995.

Noel Ignatiev How the Irish Became White Routledge 1995. 
Ignatiev How the Irish Became White p. 59.

Buffy the Vampire Slayer: The Watcher's Guide, vol 1, p. 41.

Buffy the Vampire Slayer: The Watcher's Guide, vol 1, p. 45.

Buffy the Vampire Slayer: The Watcher's Guide, vol 1, p. 232.

Dale Maharidge The Coming White Minority: California, Multiculturalism, and America's Future Vintage Books 1999, p. xvii.

Maharidge The Coming White Minority p. xvii.

Maharidge The Coming White Minority, p. 3.

Maharidge The Coming White Minority, p. 13.

Maharidge The Coming White Minority, p. 14.

Maharidge The Coming White Minority, p. 7.

It is interesting to note that, commenting on the battle for the citadel of Chapultepec during the American-American War, an American officer said that the Mexican cadets fought 'like demons'. Maharidge The Coming White Minority, p. 23.

Maharidge The Coming White Minority, p. 11.

From this point of view Buffy the Vampire Slayer can be understood as a conservative feel-good program for white Americans. It enables them to avoid the pressing problems of living in an increasingly diverse and racialised society. This is one way of accounting for the exceptional amount of academic interest that has already been expended on the program, something that I outlined in note 1 . Basically, it allows white academics to avoid confronting the real issues of present-day American society.

Buffy the Vampire Slayer: The Watcher's Guide, vol 1, p. 197.

On Jews and cultural pluralism in the USA see my 'Making Social Space for Jews in America' in Stratton Coming Out Jewish.

Andrew Yule Spielberg: Father of the Man Warner Books 1997, p. 18.

Buffy the Vampire Slayer: The Watcher's Guide, vol 1, p. 250.

Buffy the Vampire Slayer: The Watcher's Guide, vol 1, p. 28.

Buffy the Vampire Slayer: The Watcher's Guide, vol 1, p. 28.

See Karen Brodkin How Jews Became White Folks and What that Says about Race in America Rutgers University Press 1998. 
Paul Brienes Tough Jews: Political Fantasies and the Moral Dilemma of American Jewry Basic Books 1990.

Buffy the Vampire Slayer: The Watcher's Guide, vol 1, p. 129.

This is all told in 'The Harvest' and it can also be found in the Master's biography in Buffy the Vampire Slayer: The Watcher's Guide, vol 1, pp. 129-130.

We can note, in connection with the term Hellmouth, that, according to Lucia Ruedenberg-Wright in 'The Second and Third Generations, Where do we go from here', '[Many] children of survivors who live in Germany today, whether by choice or because they were born there to survivor parents [describe themselves as having] settled "in the mouth of the beast"'.

Benjamin Franklin "CHIT CHAT AROUND THE TABLE DURING INTERMISSION," at the Philadelphia Constitutional Convention of 1787. This statement was recorded in the dairy of Charles Cotesworth Pinckney, a delegate from South Carolina. To be found at: http://www.biblebelievers.org.au/clilist.htm

Quoted here from Ivan Kalmar The Trotskys, Freuds and Woody Allens: Portrait of a Culture Viking 1993, p. 49.

Adolf Hitler Mein Kampf vol 1, p. 358.

'Anti-Semitism Worldwide 1998/9: 'Netherlands' at http://www.tau.ac.il:81/AntiSemitism/asw98 9/nether.html

For a short discussion see Jon Stratton 'Thinking Through the Holocaust: A discussion inspired by Hilene Flanzbaum (ed.), The Americaniozation of the Holocaust' in Continuum: Journal of Media and Cultural Studies, vol 14, no 2, 2000, pp. 231-245.

Brienes Tough Jews, p. 71.

Jeffrey Shandler While America Watches: Televising the Hol,ocaust Oxford University Press 1999, p. 167.

Shandler While America Watches, p. 168.

Saul Friedlander ed. Probing the Limits of Representation: Nazism and the "Final Solution” Harvard University Press 1992.

Yosefa Loshitzky 'Introduction’ to Yosefa Loshitzky ed. Spielberg's Holocaust: Critical Perspectives on Schindler’s List Indiana University Press 1997, p. 2.

Yosefa Loshitzky ‘Introduction’, p. 3.

Marianne Hirsch Family Frames Harvard University Press 1997, p. 22. 
50 In 'Welcome to the Hellmouth' there is an intriguing moment when Buffy, hunting a vampire, is surprised by Cordelia and her friends. Buffy nearly kills her, to which Cordelia responds by exclaiming: 'God, what is your childhood trauma?'

Ruth Leys Trauma: A Genealogy University of Chicago Press 2000, p. 23.

Lucia Ruedenberg-Wright 'The Second and Third Generations, Where do we go from here' at http://lrw.net/ lucia/pubs/ajs/

Ruedenberg-Wright 'The Second and Third Generations'

'My Grandfather's Story by Gilad Evrony' at The Third Generation Holocaust Web Page, www.holocaust3rdgen.com

In 'Becoming, Part 1', Buffy tells her mother that she'd love to be 'upstairs watching TV or gossiping about boys, or, God, even studying. But I have to save the world. Again.' 